\title{
PENERAPAN MODEL PEMBELAJARAN KOOPERATIF TIPE SNOWBALL THROWING UNTUK MENINGKATKAN HASIL BELAJAR SISWA KELAS XI MATERI LINGKUNGAN HIDUP DAN PEMBANGUNAN BERKELANJUTAN SMA NEGERI 1 LASALIMU SELATAN
}

(Penelitian Tindakan Kelas Terhadap Siswa Kelas XI SMA Negeri 1 Lasalimu Selatan)

\begin{abstract}
Sumarlin 1
${ }^{1}$ Alumni Pendidikan Geografi FKIP UHO

Abstrak :Tujuan dalam penelitian ini adalah : 1) Untuk mendeskripsikan aktivitas belajar siswa kelas XI SMA Negeri 1 Lasalimu Selatan yang diajar dengan megunakan model pembelajaran kooperatif tipe snowbal throwing pada materi lingkungan hidup dan pembangunan berkelanjutan, 2) Untuk mendeskripsikan hasil belajar geografi siswa kelas XI di SMA Negeri 1 Lasalimu Selatan yang diajarkan dengan menggunakan model pembelajaran kooperatif tipe Snowball throwing pada materi pokok lingkungan hidup dan pembangunan berkelanjutan, 3) Untuk mengetahui peningkatan hasil belajar geografi siswa kelas XI di SMA Negeri 1 Lasalimu Selatan yang diajarkan dengan menggunakan model pembelajaran kooperatif tipe Snowball throwing pada materi pokok lingkungan hidup dan pembangunan berkelanjutan.Berdasarkan analisis data diperoleh kesimpulan bahwa : 1) Model pembelajaran Kooperatif Tipe Snowball Throwing pada skor rata-rata aktivitas siklus I sebesar 2,6 termaksut kategori cukup meningakat pada siklus II menjadi 3,6 termaksut pada kategori baik; 2) Aktivitas mengajar guru dengan menerapkan model pembelajaran Kooperatif Tipe Snowball Throwing dengan skor rata-rata pada siklus I adalah 2,67 yang termaksut kategori cukup dan meningkat pada siklus II menjadi 3,67 yang berkategori baik; 3) Terjadi peningkatan hasil belajar siswa XI SMA Negeri 1 Lasalimu Selatan dari siklus I ke siklus II. Pada siklus satu I dari 29 orang siswa hanya 19 orang siswa yang tuntas dengan presentase ketuntasan $65,5 \%$ dengan nilai rata-rata 70 . Pada siklus II mengalami peningkatan yaitu dari 29 orang siswa ada 26 orang siswa yang tuntas dengan presentase ketuntasan $89,7 \%$ dengan nilai rata-rata $76,6 \%$.
\end{abstract}

Kata Kunci : Model Pembelajaran, Snowball Throwing, Hasil Belajar 


\title{
APPLICATION OF COOPERATIVE LEARNING SNOWBALL TYPE TO INCREASE LEARNING RESULTS STUDENT CLASS XI ENVIRONMENT AND SUSTAINABLE DEVELOPMENT SUBJECT SMA NEGERI 1 LASALIMU SELATAN
}

(Class Action Research Against Students of Class XI SMA Negeri 1 Lasalimu Selatan)

\section{Sumarlin 1}

${ }^{1}$ Alumni of Geography Education of Halu Oleo University

\begin{abstract}
The objectives of this research are: 1) To describe the learning activity of grade XI students of SMA Negeri 1 Lasalimu Selatan taught by using cooperative learning model of snowbal throwing type on environmental material and sustainable development 2) To describe the learning result of geography of class XI in SMA Negeri 1 Lasalimu Selatan taught by using cooperative learning model type of snowball throwing on the basic material of environment and sustainable development, 3) To know the improvement of geography learning result of class XI students in SMA Negeri 1 Lasalimu Selatan taught by using cooperative learning model type Snowball throwing on the subject matter of environment and sustainable development. Based on the data analysis, it can be concluded that: 1) Cooperative learning model of Snowball Throwing Type on average score of activity of cycle I of 2.6 in the category category is quite meningakat in cycle II to 3.6 in the good category; 2) Teacher's teaching activity by applying cooperative learning model of type snowball throwing with average score in cycle $\mathrm{I}$ is 2.67 which categorized enough category and increase in cycle II become 3,67 which categorized good; 3) Increased student learning outcomes XI SMA Negeri 1 Lasalimu Selatan from cycle I to cycle II. In the first cycle I of 29 students only 19 students who completed with a percentage mastery $65.5 \%$ with an average value of 70 . In cycle II has increased from 29 students there are 26 students who completed with a percentage of completeness $89.7 \%$ with an average score of $76.6 \%$.
\end{abstract}

\section{Keywords: Learning Model, Snowball Throwing, Learning Outcomes}

\section{PENDAHULUAN}

Penggunaan model pembelajaran hendaknya bukan hanya guru saja yang aktif dalam proses pembelajaran, melainkan diharapkan terjadinya interaksi antara guru dan siswa serta siswa dengan siswa. Salah satu upaya untuk meningkatkan kualitas sumber daya manusia adalah pembelajaran di sekolah. Oleh karena itu, masalah kualitas pembelajaran Geografi memerlukan perhatian yang serius dari pihak-pihak yang terkait khususnya yang melaksanakan proses belajar di dalam kelas. Guru sangat berperan penting dalam perbaikan proses pengajaran. Guru sepatutnya mampu mencari strategi yang dipandang dapat membelajarkan siswa melalui proses pengajaran yang dilaksanakan agar tujuan pengajaran dapat tercapai secara efektif dan hasil belajar siswa dapat ditingkatkan. Dengan adanya perencanaan yang baik, akan mendukung keberhasilan pengajaran. Salah satu upaya untuk meningkatkan sumber daya manusia adalah melalui proses pembelajaran di sekolah karenanya tenaga pendidik (guru) merupakan elemen kunci dalam sitem pendidikan khususnya di sekolah (Departemen Pendidikan Nasional, 2008).

Usaha meningkatkan kemampuan guru dalam belajar mengajar, perlu pemahaman ulang.Mengajar tidak sekedar mengkomunikasikan pengetahuan agar dapat belajar, tetapi mengajar juga berarti usaha menolong individu pelajar agar mampu memahami konsep-konsep dan dapat menerapkan konsep yang dipahami. Dalam proses pembelajaran, guru perlu menerapkan model pembelajaran yang sesuai dengan 
karakteristik materi pokok untuk mencapai tujuan pembelajaran.

Dari fenomena tersebut, maka peneliti mengupayakan penggunaan suatu model pembelajaran yang dapat memungkinkan terjadinya aktivitas belajar, saling berinteraksi dengan sesama secara aktif, dan efektif melalui sebuah model pembelajaran yang disebut pembelajaran kooperatif tipe snowball throwing diharapkan siswa dapat lebih intensif belajar sehingga akan menguasai materi pelajaran dengan mudah, karena siswa lebih mudah memahami penjelasan dari kawannya dibanding penjelasan guru karena taraf pengetahuan serta pemikiran mereka lebih sejalan dan sepadan. Selain itu, penelitian juga menunjukkan bahwa pembelajaran kooperatif memiliki dampak positif terhadap siswa yang rendah hasil belajarnya.

Salah satu model pembelajaran yang digunakan adalah pembelajaran kooperatif tipe Snowball Throwing.Snowball Throwing diterapkan karena model pembelajaran ini mempunyai peran dalam upaya meningkatkan aktivitas belajar siswa dan dapat mendongkrak hasil belajar siswa yang masih tergolong rendah. belum sepenuhnya diterapkan oleh guru guru di SMA Negeri 1 Lasalimu Selatan karena disebabkan oleh beberapa hal diantaranya: kurangnya sarana dan prasarana yang cukup memadai disekolah, kurangnya kemampuan dan pemahaman guru untuk merancang model pembelajaran yang bervariasi dalam melaksanakan proses belajar mengajar sehingga membuat siswa cendrung pasif, siswa kurang antusias dalam pelaksanaan belajar mengajar khususnya mata pelajaran kebosanan murid dalam menyalin catatan pelajaran yang di berikan oleh guru, sehingga siswa terkesan tidak serius dalam menerima pelajaran, dan guru dalam proses belajar mengajar kebanyakan menggunakan metode ceramah. Metode ceramah selain mempunyai kelebihan, ceramah juga memiliki kelemahan salahsatunya siswa akan sulit mengetahui apakah seluruh siswa sudah mengerti apa yang di jelaskan atau belum. (Wina Sanjaya,2006:148).
Berdasarkan fakta dari hasil observasi awal terhadap guru mata pelajaran Geografi kelas XI SMA negeri 1 Lasalimu Selatan pada tanggal 10 Januari 2016/2017 diketahui bahwa model pembelajaran yang diterapkan di kelas XI SMA Negeri 1 Lasalimu Selatan selama ini adalah pengajaran yang masih berpusat pada guru kemudian memberikan soal (penugasan) kepada siswa dengan materi terbatasdan kurangnya pemahaman guru untuk merancang model pembelajaran yang bervariasi dalam melaksanakan proses belajar mengajar, sehingga membuat siswa cendrung pasif, siswa kurang antusias dalam pelaksanaan belajar mengajar khususnya mata pelajaran Geografi kebosanan murid dalam menyalin catatan pelajaran yang di berikan oleh guru sehingga siswa terkesan tidak serius dalam menerima pelajaran, guru dalam proses belajar mengajar kebanyakan menggunakan metode ceramah karena dianggap mudah dan gampang untuk diterapkan sehingga siswa tidak terlibat secara aktif pada pelajaran Geografi yaitu selama kegiatan pembelajaran siswa jarang sekali mengajukan pertanyaan serta kurang mampu untuk berkerja sama dalam kelompok, siswa juga kurang termotivasi untuk mengerjakan tugas yang di berikan oleh guru dan siswa kebanyakan mendengarkan dan menyalin apa yang disampaikan oleh guru, serta menyebabkan siswa menjadi jenuh dan bosan dengan materi yang diajarkan pada akhirnya berdampak pada hasil belajar.

Hal ini mengakibatkan minat atau perhatian dan aktivitas siswa kurang, serta muncul anggapan bahwa pelajaran Geografi itu tidak semudah yang dipikirkan.Akibatnya, berpengaruh pada hasil belajar yang bisa ditetapkan di sekolah belum mencapai standar Kriteria Ketuntasan Minimal (KKM), khususnya untuk materi lingkungan hidup dan pembangunan berkelanjutan. Hal ini, dapat dilihat pada persentase ketuntasan belajar hanya mencapai $50 \%$ dimana nilai rata-rata hasil ulangan harian siswa kelas XI SMA Negeri 1 Lasalimu Selatan pada semester genap tahun 2016/2017 ditunjukan dengan rata-rata 65 dari 29 siswa terdapat 14 siswa atau 50\% yang belum mencapai KKM yang ditetapkan

Sumarlin, 
oleh sekolah yaitu 70 (tujuh puluh) untuk mata pelajaran Geografi ,sesuai informasih yang di berikan oleh Guru SMAN 1 Lasalimu Selatan.

Atas dasar itulah maka peneliti melakukan penelitian tentang : "Penerapan Model Pembelajaran Kooperatif Tipe Snowball ThrowingUntuk Meningkatkan Hasil Belajar Siswa Kelas XI Materi Lingkungan Hidup dan Pembangunan Berkelanjutan SMA Negeri 1 Lasalimu Selatan.

Pembelajaran kooperatif adalah suatu srategi pembelajaran dimana siswa belajar dan bekerja dalam kelompok-kelompok kecil secara kolaboratif yang anggotanya terdiri 2 sampai 5 orang, dengan struktur kelompoknya bersifat heterogen. (Kokom Komalasari,2010;62).

$$
\text { Menurut Sanjaya dalam }
$$

(Rusman,2011:105) model pembelajaran kooperatifakan efektif digunakan apabila:

1) Guru menekankan pentingnya usaha bersama di samping usaha secara individual.

2) Guru menghendaki pemerataan perolehan hasil dalam belajar.

3) Guru ingin menanamkan tutor sebaya atau belajar melalui teman sendiri.

4) Guru menghendaki adanya pemerataan partisipasi aktif siswa.

5) Guru menghendaki kemampuan siswa dalam memecahkan berbagai permasalahan.

Model pembelajarankooperatif merupakan model pembelajaran yang banyak digunakan dan menjadi perhatian serta dianjurkan oleh para ahli penelitian. Hal ini dikarenakan berdasarkan penelitian yang dilakukan oleh Slavin dinyatakan bahwa:

(a) Penggunaan pembelajaran kooperatif dapat meningkatkan hubungan sosial, menumbuhkan sikap toleransi, dan menghargai pendapat orang lain.

(b) Pembelajaran kooperatif dapat memenuhi kebutuhan siswa dalam berfikir kritis, memecahkan masalah, dan mengintegrasikan pengetahuan dengan pengalaman.

Menurut Ismail, (2003:) Snowball throwing berasal dari dua suku kata yaitu "Snowball" dan "throwing". Kata Snowball berarti bola salju, sedangkan throwing berarti melempar, jadi Snowball Throwing merupakan salah satu model dari pembelajaran kooperatif. Pembelajran Snowball Throwing merupakan model pembelajaran yang membagi murid didalam beberapa kelompok, yang dimana masingmasing angota kelompok membuat bola pertanyaan,. Dalam pembuatan kelompok, siswa dapat dipilih secara acak atau heterogen. Hal ini diungkapkan oleh para ahli berikut ini.

Menurut Suprijono, (20011:8) Snowball Throwing adalah suatu cara penyajian bahan pelajaran dimana murid dibentuk dalam beberapa kelompok yang heterogen kemudian masing masing kelompok dipilih ketua kelompoknya untuk mendapat tugas dari guru lalu masing masing murid membuat pertanyaan yang di bentuk seperti bola (kertas pertanyaan) kemudian dilempar ke murid lain yang masing-masing murid menjawab pertanyaan dari bola yang diperoleh.

Belajar merupakan komponen dari ilmu pendidikan yang berkenaan dengan tujuan dan bahan acuan interaksi.Didalamnya dikembangkan teoriteori yang meliputi teori tentang tujuan pendidikan, organisasi kurikulum, isi kurikulum, dan modul-modul pengembangan kurikulum. (Sagala, 2008:12

Pembelajaran ialah membelajarkan siswa menggunakan asas pendidikan maupun teori belajar merupakan penentu utama keberhasilan pendidikan. Pembelajaran merupakan proses komunikasi dua arah, mengajar dilakukan oleh pihak guru sebagai pendidik, sedangkan belajar dilakukan oleh peserta didik atau murid. (Sagala, 2009:15)

Sedangkan hasil belajar menurut Nana Sudjana dalam bukunya yaitu adalah 
kemampuan kemampuan yang dimiliki siswa setelah ia menerima pengalaman belajarnya.(Bandung: PT Remaja Rosdakarya, 2010).

\section{METODE PENELITIAN}

\section{Tempat dan Waktu Penelitian}

Penelitian ini dilaksanakan pada semester genap pada tahun ajaran 2017/2018 di SMA Negeri Lasalimu Selatan pada kelas XI, J1 poros Bau-bau Kec. Lasalimu Selatan Desa Ambuau. Penelitian ini akan dilaksanakan pada bulan Februari sampai dengan Maret tahun ajaran $2017 / 2018$.

\section{Subyek Penelitian}

Subyek penelitian ini adalah siswa kelas XI IPS 1 SMA Negeri 1 Lasalimu Selatan yang terdaftar tahun pelajaran 2017/2018, yang berjumlah 29 orang terdiri dari 13 siswa laki-laki dan 16 siswa perempuan. Penetapan kelas XI berdasarkan hasil observasi awal penelitian pada tanggal 10 Januari 2016/2017, dimana hasil belajar siswa pada materi lingkungan hidup dan pembanguan berkelanjutan belum memenuhi KKM.

\section{Jenis Penelitian}

Jenis penelitian ini adalah Penelitian Tindakan Kelas.PTK ini dilakukan dengan menerapkan model pembelajaran kooperatif tipe snowball throwing sebagai alternatif tindakan untuk meningkatkan hasil belajar geografi siswa kelas XI SMA Negeri 1 Lasalimu Selatan.

\section{Faktor Yang Diteliti}

Faktor yang diperhatikan dalam penelitian ini adalah :

1. Faktor siswa : faktor yang diperhatikan adalah aktivitas dan hasil belajar siswa dalam memahami konsep tentang materi lingkungan hidup dan pembangunan berkelanjutan.
2. Fakor guru : melihat aktivitas guru dalam penerapan model pembelajaran kooperatif tipe snowball throwing dalam proses pembelajaran dikelas.

\section{Desain Penelitian}

Penelitian tindakan kelas ini akan dilaksanakan sebanyak dua siklus dengan tiap siklus dilaksanakan sesuai dengan perubahan yang ingin dicapai pada faktorfaktor yang diteliti. Berdasarkan observasi awal dan diskusi dengan guru bidang studi Geografi, ditetapkan bahwa tindakan yang digunakan untuk meningkatkan hasil belajar Geografi khususnya pada materi pokok lingkungan hidup dan pembangunan berkelanjutan adalah memberikan pembelajaran dengan menggunakan model pembelajaran kooperatif tipe snowball throwing.

Desain model penelitian tindakan kelas (PTK) ini terdiri atas 4 (empat) tahap, yakni : perencanaan, pelaksanaan tindakan, pengamatan dan refleksi. Secara rinci penelitian tindakan kelas ini dapat dijabarkan sebagai berikut:

\section{Perencanaan (Planing)}

Pada tahap perencanaan kegiatan akan dilakukan langkah-langkah sebagai berikut:

a. Membuat skenario pembelajaran berupa rencana pelaksanaan pembelajaran (RPP) dengan model pembelajaran kooperatif tipe snowball throwing tentang materi lingkungan hidup dan pembangunan lingkungan hidup.

b. Membuat/menyiapkan media/alat bantu termasuk lembar observasi keaktifan dan partisipai aktif siswa dalam kegiatan pembelajaran dan kemampuan guru dalam menetapkan model pembelajaran kooperatif tipe snowball throwing tentang materi lingkungan hidup dan pembangunan berkelanjutan.

\section{Pelaksanaan Tindakan (Action)}


Kegiatan yang dilaksanakan pada tahap ini yaitu melaksanakan skenario pembelajaran kooperatif tipe snowball throwing dengan berdasarkan skenario pembelajaran RPP pada materi lingkungan hidup dan pembanguan berkelanjutan.

\section{Pengamatan (Observation)}

Kegiatan observasi dilaksanakan untuk mendapatkan informasi bagaimana kemampuan guru dalam membimbing dan memfasilitasi siswa dalam kegiatan proses pembelajaran. Observasi dilakukan oleh guru pengamat dan menggunakan lembar observasi berupa pengamatan guru dalam menerapkan model pembelajaran kooperatif tipe snowball throwing

\section{Refleksi}

Peneliti melaksanakan diskusi dengan pengamat untuk merefleksi hasil observasi yang dilakukan.Refleksi dilakukan untuk mengkaji hal-hal yang telah dan belum dicapai.Hasil refleksi digunakan untuk menetapkan langkah-langkah lebih lanjut pada siklus berikutnya. Kelemahankelemahan yang ada serta kurangnya hasil belajar siswa pada siklus I akan dilakukan perbaikan pembelajaran pada siklus II.

\section{Data dan Tehnik Pengumpulan Data}

\section{Jenis Data}

Jenis data yang di peroleh adalah kualitatif dan kuantitatif. Data kualitatif berupa aktivitas guru dan siswa yang di peroleh dari lembar observasi, sedangkan data kualitatif berupa hasil belajar siswa yang di peroleh dari tes hasil belajar

\section{Sumber Data}

Sumber data penelitian adalah guru dan siswa yang meliputi:

a. Hasil observasi aktivitas belajar siswa

b. Hasil observasi aktivitas mengajar guru

c. Hasil belajar siswa.

\section{Tehnik Pengumpulan Data}

Tehnik pengumpulan data dalam penelitian ini adalah

a. Data mengenai aktivitas belajar siswa dan mengajar guru di ambil dengan menggunakan lembar observasi dengan cara memberikan skor pada aspek aktivitas yang di lakukan sesuai dengan criteria yang telah di tentukan.

b. Data mengenai hasil belajar Geografi siswa sebagai tolak ukur penguasaan siswa pada materi menggunakan model pembelajaran kooperatif tipe snowball throwing di ambil dengan menggunakan tes hasil belajar (tes siklus).Tehnik tersebut di lakukan setelah pelaksanaan tindakan untuk menilai hasil belajar.

\section{Teknik Analisis Data}

Data dalam penelitian ini dianalisis dengan menggunakan analisis statistik deskriptif kualitatif dan kuantitatif. Analisis deskriptif kualitatif di gunakan untuk memberikan penjelasan mengenai aktivitas siswa serta kemampuan guru selama proses pembelajaran berlangsung. Analisis deskritif kuantitatif di gunakan untuk menyajikan presentase aktivitas guru dalam mengelolah pembelajran, presentase aktivitas siswa dan presentase ketuntasan hasil belajar siswa. Adapun rumus yang digunakan dalam menganalisis data adalah :

1. Menentukan hasil belajar siswa secara individual

Untuk menentukan nilai hasil belajar siswa dapat menggunakan rumus :

$$
\mathrm{Xi}=\frac{\mathrm{Spi}}{\mathrm{Sm}} \times 100
$$

Keterangan :

$\mathrm{Xi}=$ nilai yang diperoleh siswa ke-i

Spi $=$ skor yang diperoleh siswa ke-i

$\mathrm{Sm}=$ skor maksimal

(Usman dan Setiawati, 2001)

2. Menentukan nilai rata-rata hasil belajar siswa dengan rumus: 
Dengan:

$$
\bar{X}=\frac{\sum_{\mathrm{i}=1}^{\mathrm{n}} \mathrm{X}_{\mathrm{i}}}{\mathrm{n}}
$$

$\overline{\mathrm{X}}=$ nilai rata - rata yang diperoleh siswa

$\mathrm{n}=$ jumlah siswa secara keseluruhan

$\mathrm{Xi}=$ nilai yang diperoleh tiap siswa

(Sudjana, 2002: 67)

3. Menentukan tingkat pencapain ketuntasan belajar secara klaiskal

Presentase jumlah siswa yang hasil

belajarnya sudah tuntas dapat menggunakan rumus sebagai berikut :

$\%$ Tuntas $=$ Tuntas $=\frac{\sum \mathrm{TB}}{\mathrm{N}} \mathrm{x} 100 \%$

Keterangan :

$\sum \mathrm{TB}=$ jumlah siswa yang tuntas belajar

$\mathrm{N}=$ jumlah siswa secara keseluruhan

(Sudjana, 2002)

4. Mengklasifikan rata-rata skor aktivitas siswa sebagai berikut :

$$
\begin{array}{ll}
1 \leq \mathrm{Xi}<2 & : \text { kategori kurang } \\
2 \leq \mathrm{Xi}<3 & : \text { kategori cukup } \\
3 \leq \mathrm{Xi}<4 & : \text { kategori baik } \\
\mathrm{Xi}=4 & \text { :kategori sangat baik }
\end{array}
$$

(Susetyo, 2010)

Penjelasan kategori rata-rata aktivitas siswa adalah sebagai berikut :

a) Kategori sangat baik jika dalam satu kelompok terdapat lima sampai enam siswa atau semua siswa mampu menerapkan semua satuan aktivitas yang dinilai.

b) Kategori baik jika dalam satu kelompok terdapat satu sampai dua siswa yang kurang mampu menerapkan semua satuan aktivitas yang dinilai. c) Kategori cukup jika dalam satu kelompok terdapat tiga sampai empat

d) siswa yang kurang mampu menerapkan semua satuan aktivitas yang dinilai.

e) Kategori kurang jika dalam satu kelompok terdapat lima sampai enam siswa yang kurang mampu menerapkan semua satuan aktivitas yang dinilai.

\section{Indikator Keberhasilan}

Indikator keberhasilan dalam penelitian ini terdiri dari indikator keterlaksanaan skenario pembelajaran dan indikator peningkatan hasil belajar siswa. Pelaksanaan tindakan kelas ini dipandang berhasil apabila sudah memenuhi kriteria keberhasilan yaitu :

\section{a. Segi Proses}

Segi proses penelitian tindakan kelas ini dikatakan berhasil jika :

1) Rata-rata aktivitas siswa telah memperoleh minimal 3,0.

2) Rata-rata aktivitas guru memperoleh minimal 3,0.

\section{b. Segi Hasil}

Dari segi hasil minimal $80 \%$ dari siswa secara klasikal memiliki nilai minimal sesuai dengan $\mathrm{KKM}$ adalah $\geq=70$

\section{HASIL PENELITIAN DAN PEMBAHASAN}

\section{A. Deskripsi Hasil Penelitian}

\section{Hasil Analisi Data Siklus 1}

\section{a. Data Aktivitas Belajar Siswa Siklus 1}

Untuk mendapatkan gambaran ratarata aktivitas belajar siswa selama pembelajaran pada siklus I pada pertemuan I dan II dapat dilihat pada Gambar 3.1 berikut : 


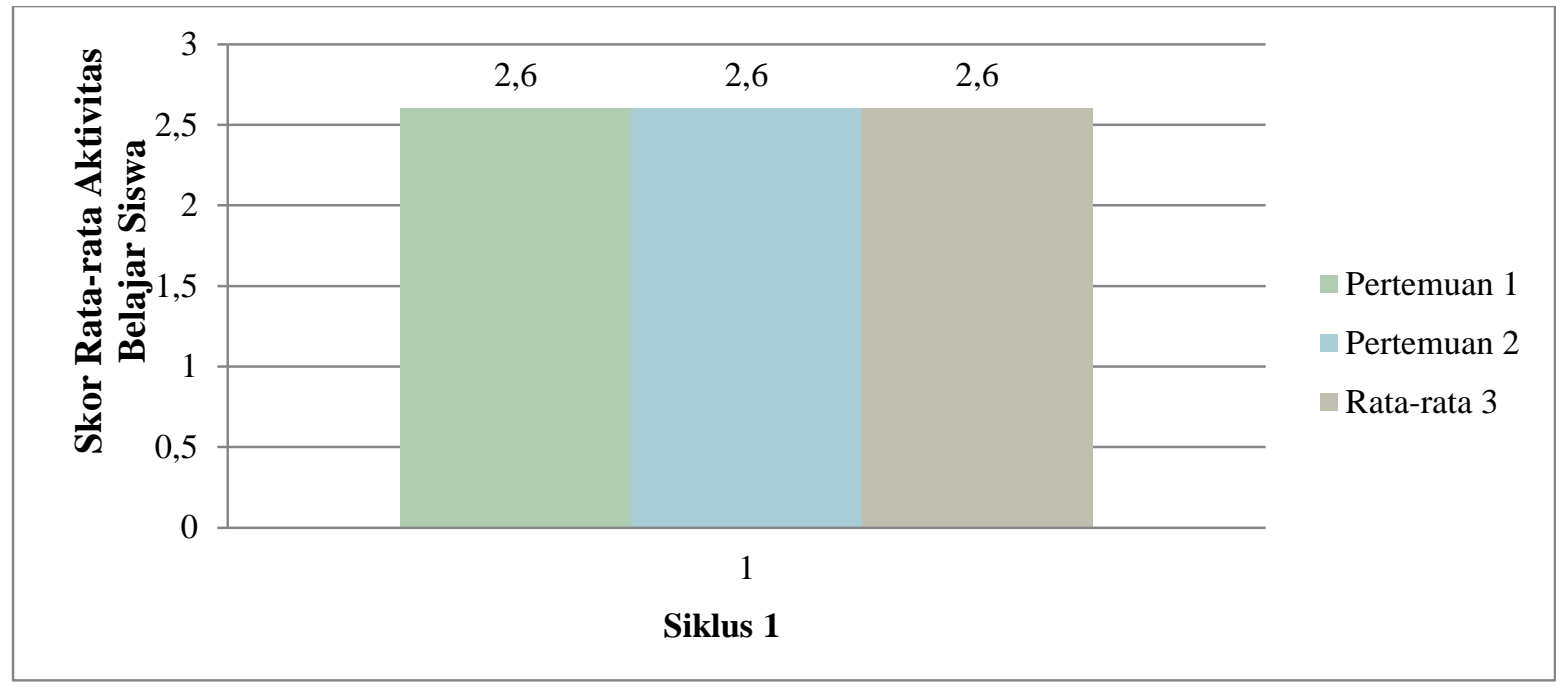

Gambar 3.1Grafik Skor Rata-Rata Aktivitas Belajar Siswa Siklus I

Berdasarkan 3.1 gambar di atas tentang hasil observasi aktivitas siswa belajar siswa dapat di peroleh gambaran bahwa, hasil aktivitas belajar siswa tersebut masih belum memenuhi criteria ketutansan minimal yaitu 3,0 karena rata-rata aktivitas belajar siswa mencapai rata-rata 2,6 yang dengan kategori Cukup.

\section{b. Data Aktivitas Guru siklus}

mendapatkan gambaran rata-rata aktivitas guru selama pembelajaran pada siklus I dan II dapat dilihat pada Gambar 3.2 berikut :

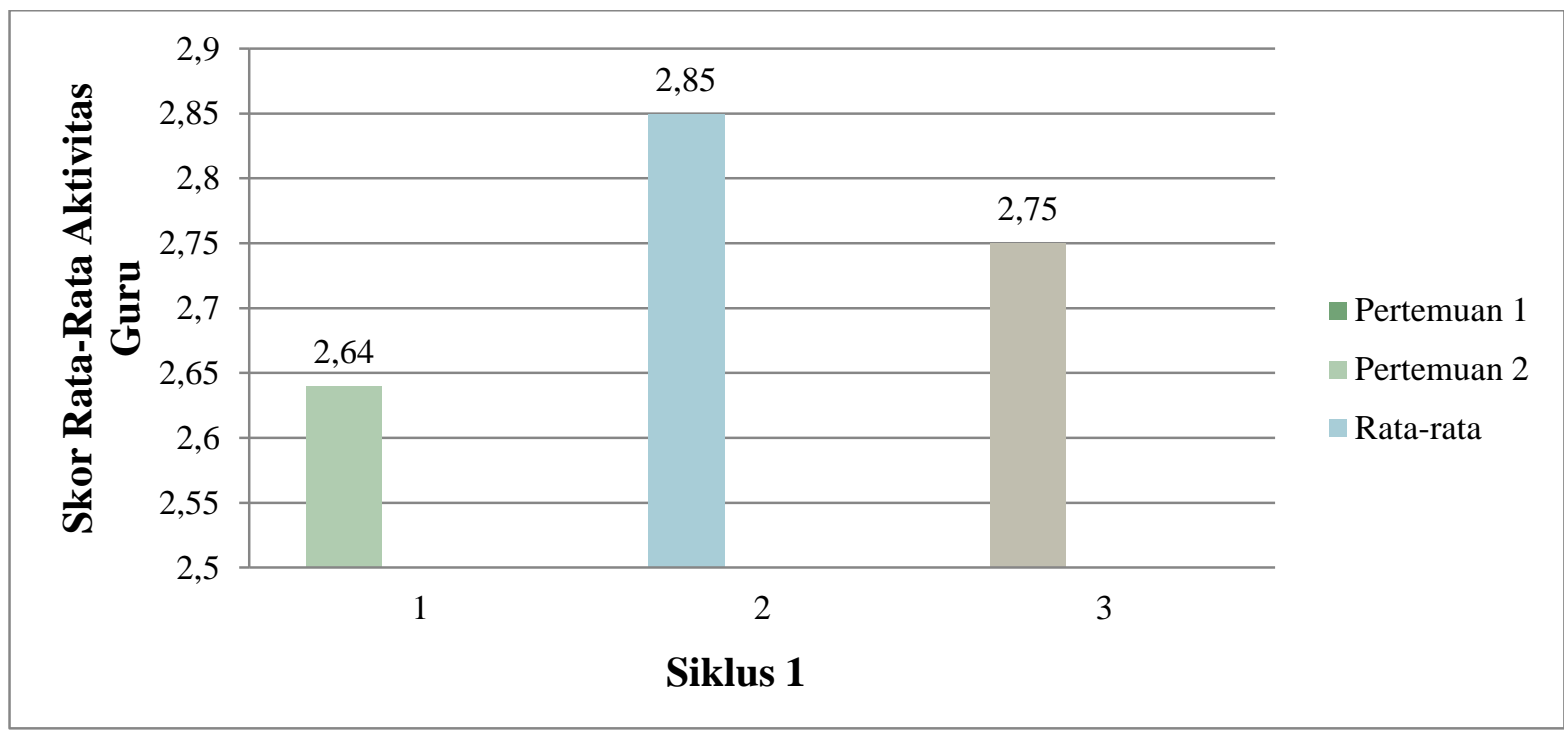

Berdasarkan gambar 3.2 di atas tentang hasil observasi aktivitas guru dapat diperoleh gambaran bahwa, hasil aktivitas guru tersebut masih belum memenuhi criteria ketuntansan minimal 3,0, karena rata-rata aktivitas guru masih mencapai rata-rata 2,67 yang berkategorikan Cukup.

\section{c. Data Hasil Belajar Siswa Siklus 1.}

Untuk lebih jelasnya mengenai gambaran hasil belajar siswa kelas XI yang di

ajar dengan menggunakan model pembelajaran kooperatif tipe Snowball 
Throwing pada siklus 1 dapat dilihat pada gambar 3.3 berikut:

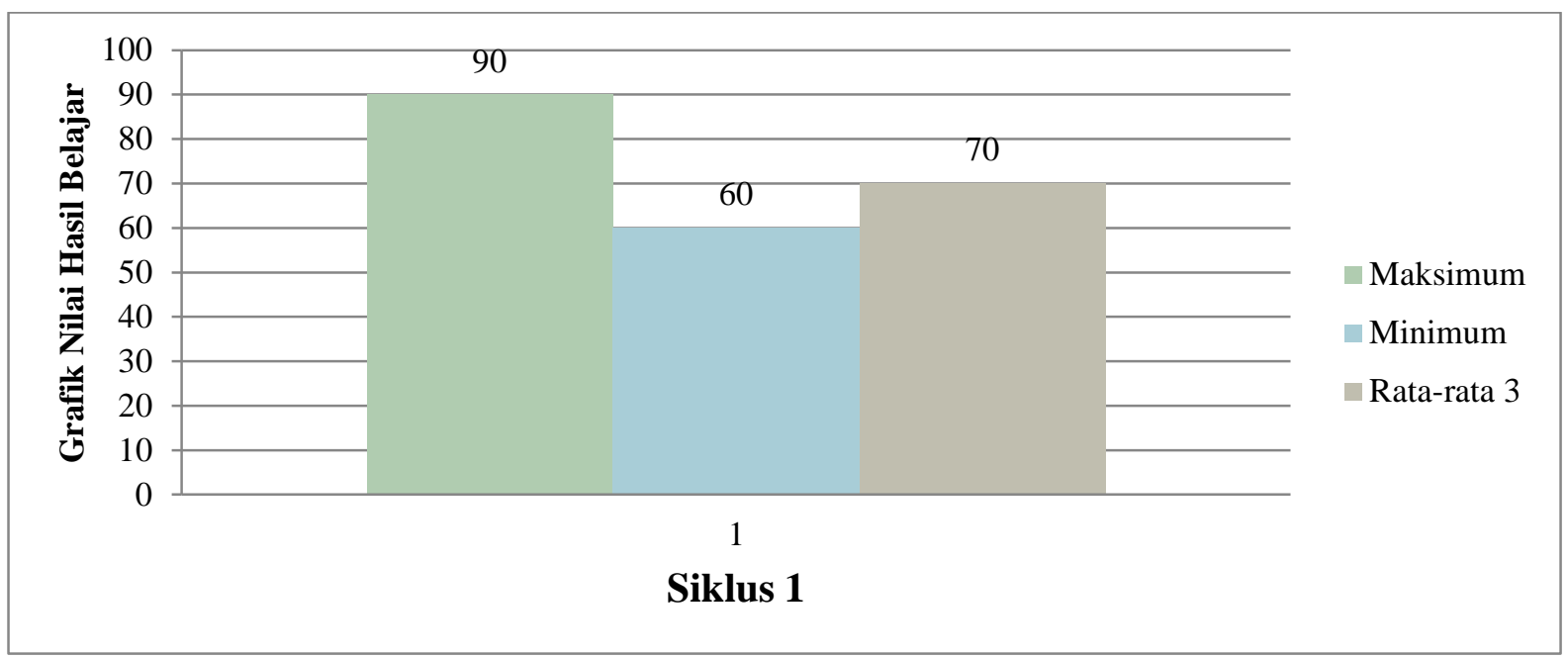

Gambar 3.3 Grafik Nilai Hasil Belajar Siklus I

Selanjutnya berdasarkan analisis ketuntasan belajar siswa pada siklus 1 diperoleh hasil sebagaimana disajikan pada Gambar 3.4berikut :

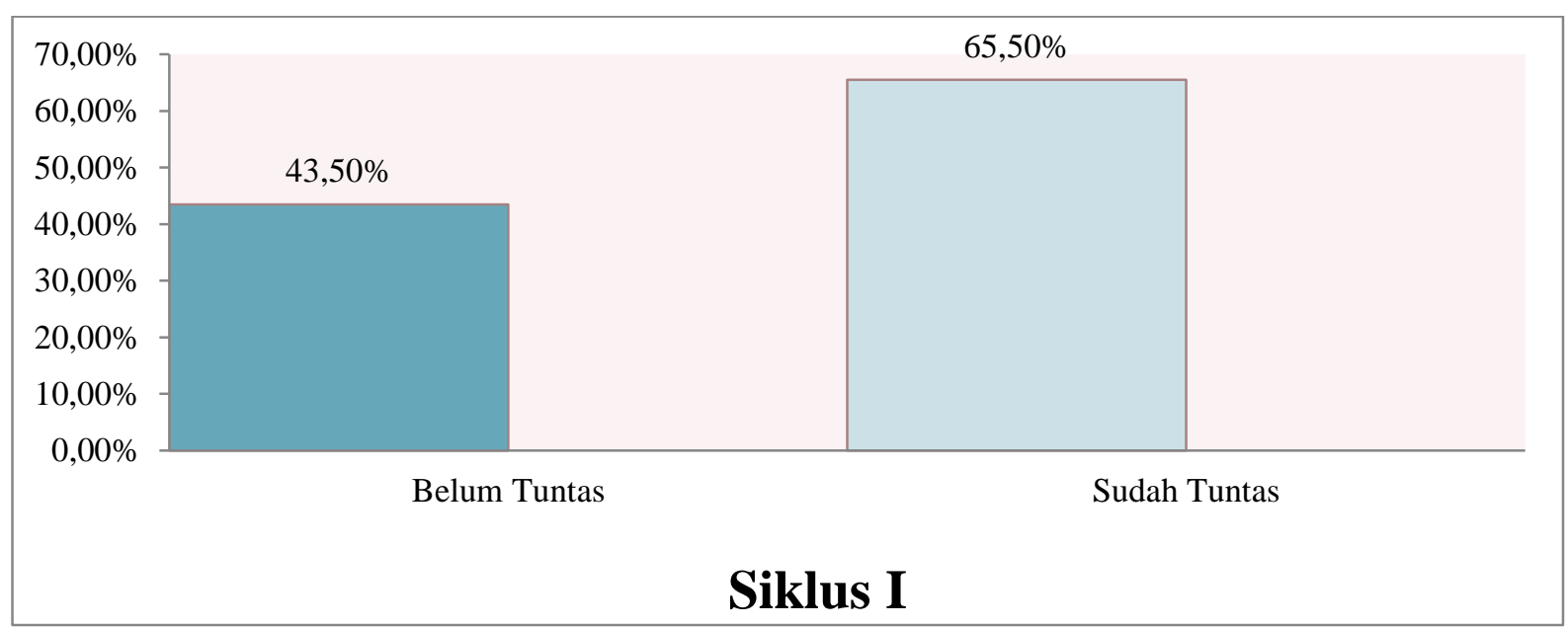

\section{Gambar 3.4 Grafik Presentase Ketuntasan Siswa Siklus I}

Gambar 3.4 diatas menunjukan bahwa ketuntasan belajar siswa pada siklus 1 yang memperolehpresentase belum tuntas $43,5 \%$, sedangkan siswa yang telah memperolehpresentaseketuntasanmencapai $65,5 \%$ namun belum mencapai indicator ketuntasan keberhasilan dimana $80 \%$ siswa mencapai ketutantasan belajar.

\section{d. Refleksi}

Pada tahap ini, peneliti bersama guru mendiskusikan kelemahan-kelemahan yang terdapat pada siklus I untuk kemudian diperbaiki pada siklus II.Pada siklus satu ini menerapkan model pembelajaran kooperatif tipe snowball throwing ini belum terlaksana dengan baik. Beberapa kelemahan tersebut antara lain:1) Dalam proses pembelajaran siswa kurang mendengarkan/memperhatikan penjelasan mengenai materi pelajaran yang di sampaikan oleh guru; 2) Siswa kurang aktif dalam proses pembelajaran sehingga siswa kurang menjawab pertanyaan yang diberikan oleh guru dengan benar; 3) Siswa 
kurang aktif dan kurang kompak untuk berdiskusi dengan kelompoknya dalam memecahkan masalah; 4) Siswa dalam proses pembelajaran Masing-masing kelompok kurang aktif dalam menyimak menanggapi mempresentasikan hasil diskusi di depan kelas. 5) siswa tidak menyimak penguatan dan koreksi dari guru tentang hasil diskusi kelompok. Dan berdasarkan refleksi aktivitas guru pada siklus 1 , terdapat beberapa kekurangan yang dialami oleh guru dalam proses pembelajran, beberapa keurangan tersebut ialah : 1) Guru kurang dalam membuka pelajaran dan memeriksa kesiapan siswa tentang materi yang akan di pelajari dan guru kurang memberikan motivasi kepada siswa agar proses pembelajaran berhasil; 2) Guru dalam mengevaluasi dan merefleksi kurang menyimpulkan terhadap hasil diskusi tentang proses mengajar; 3) guru tidak memberikan penghargaan kepada siswa tiap dari akhir diskusi.
Mengingat msaih banyak kesalahan dan kekurangan yang terjadi pada siklus 1 dalam aktivitas siswa dan aktivitas guru yang belum mencapai indicator keberhsilan dalam penelitian ini, maka penelitian dilanjutkan pada siklus 11 umtuk lebih meningkatakan kemampuan belajar geografi siswa SMA 1 Lasalimu selatan melalui pembelajran kooperatif tipe SNowball throwing, Pada siklus II dihrapkan guru agar dapat menerapkan model pembelajaran secara maksimal agar siswa yang belum memenuhi ketuntasan hasil belajar maupun yang sudah memenuhi ketuntasan belajar dapat meningkat pada siklus II sesuai yang di harapkan oleh guru.

\section{Hasil Analisi Data Siklus II}

a. Data Aktivitas Belajar Siswa Siklus II

Untuk mendapatkan dari pada gambaran rata-rata aktivitas guru selama proses pembelajaran berlangsung pada siklus II Pertemua I dan II dapat dilihat pada Gambar 3.4 berikut :

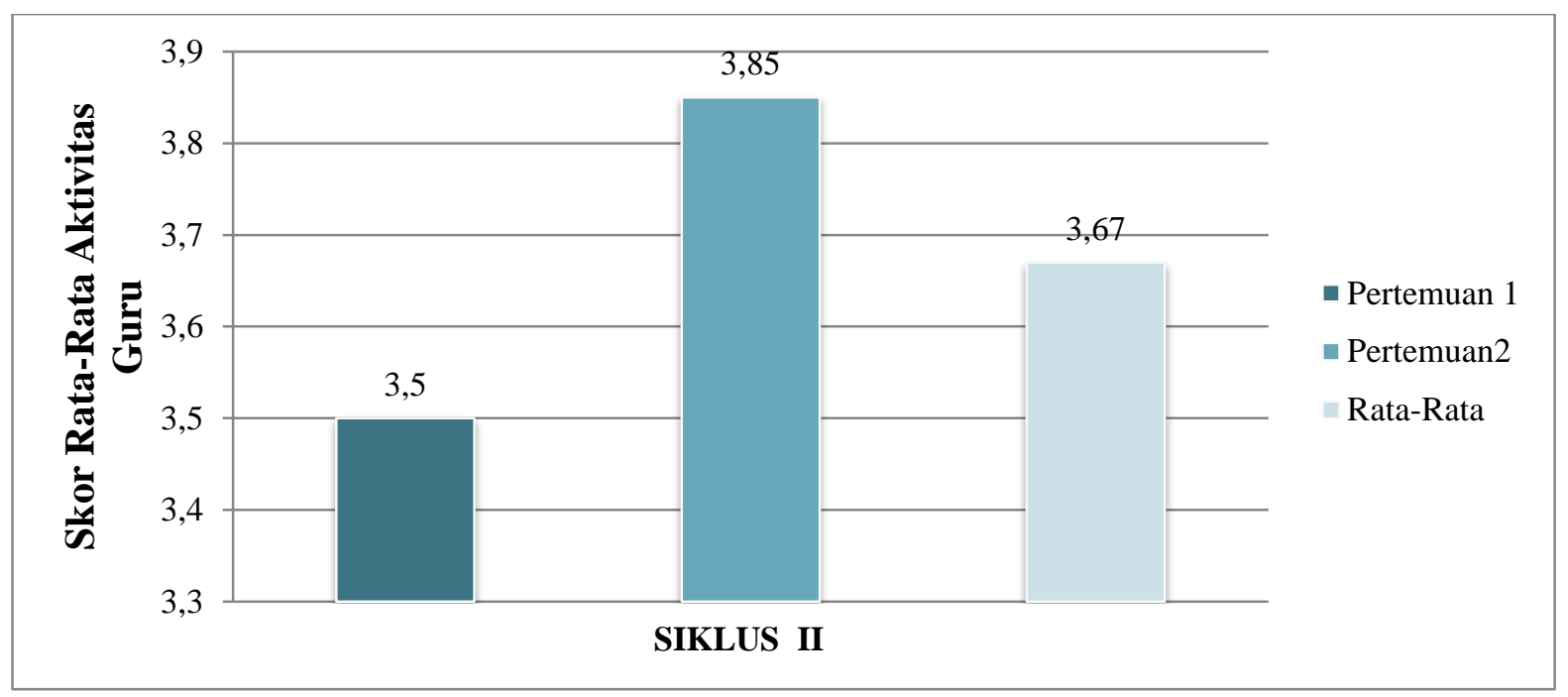

\section{Gambar 3.4 Grafik Skor Rata-rata Aktivitas Belajar Siswa Siklus II}

Berdasarkan gambar 3.4 diatas menunjukan bahwa, aktivitas belajar siswa telah memenuhi criteria ketuntasan minimal yaitu 3,0. Dimana aktivitas belajar siswa telah mencapai rata-rata 3,6 yang berkategorikan Baik.

\section{c. Data Hasil Belajar Siswa Siklus II}

Untuk lebih jelasnya mengetahui dari hasil belajar pembelajaran siswa kelas XI SMA Negeri 1 Lasalimu Selatan yang diajar dengan menerapakan menggunakan model pembelajaran Kooperatif tipe Snowball Throwingpada siklus II dan dapat dilihat pada gambar 3.5berikut : 


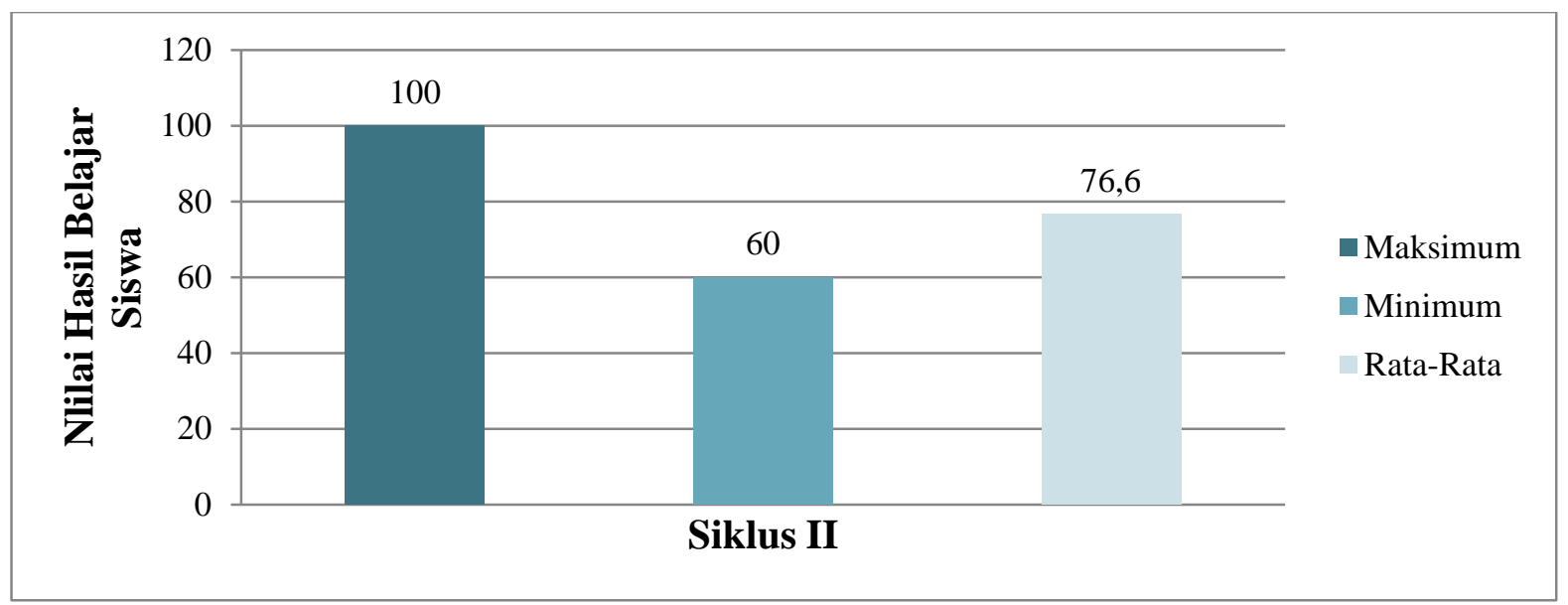

\section{Gambar 3.5.Grafik Nilai Hasil Belajar Siklus II}

Selanjutnya berdasarkan analisis ketuntasan belajar siswa pada siklus II diperoleh hasil sebagaimana disajikan pada gambar 3.6berikut :

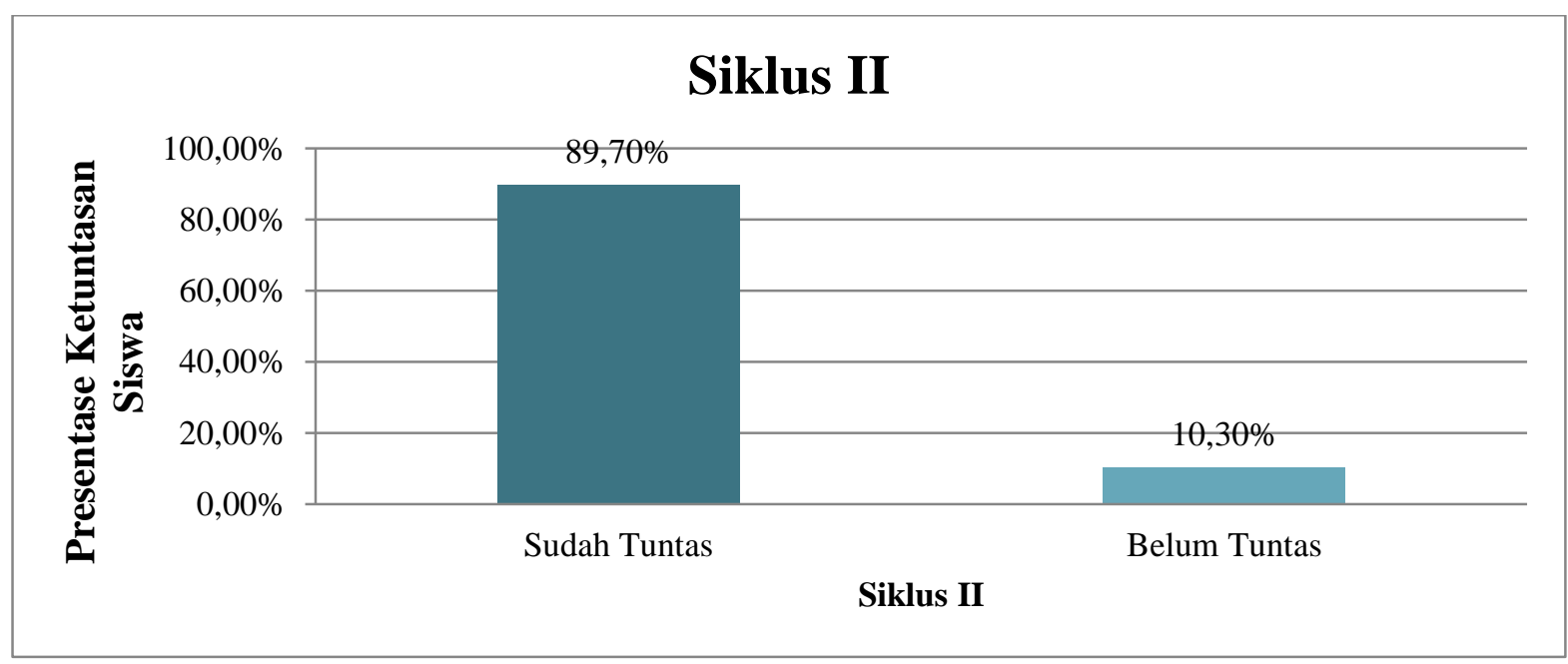

\section{Gambar 3.6Grafik Presentase Ketuntasan Siswa Siklus II}

gambar 3.6 diatas menunjukkan bahwa ketuntasan belajar siswa pada siklus II yang memperoleh presentase belum tuntas $10,3 \%$ , sedangkan siswa yang telah memperoleh dengan presentase kentuntasan mencapai $89,7 \%$. Dilihat dari peresentae dari kentuntasan siswa siklus II maka ini sudah lebih baik jika di bandingkan dengan skor perolehan siswa pada siklus I .Dalam hal ini indicator dari ketuntasan belajar siswa telah mencapai ketercapaian atau telah berhasil, dimana secara klasikal yaitu jika nilai siswa yang telah mencapai KKM 70 adalah $80 \%$, maka dikatakan hasil penelitian ini telah memenuhi standar kertercapaian atau telah berhasil.

\section{B. Pembahasan Hasil Penelitian}

\section{Aktivitas Belajar Siswa Selama KBM Berlangsung}

Berdasarkan permasalahan pertama siklus I dengan bagaimana gambaran aktivitas belajar siswa dalam proses belajar mengajar sesuai dengan materi pembahasan saat proses pembelajaran materi Lingkungan Hidup dan Pembangunan Berkelanjutan yang di ajar dengan menerapkan Model Pembelajaran Kooperatif Tipe Snowball Throwing, dapat dijelaskan gambaran berdasarkan dari hasil pengamatan pada setiap siklus, baik siklus I maupun siklus II yang menunjukan nilai peningkatan ketuntasan kertercapaian hasil belajar yang baik. Peningkatan aktivitas belajar siswa tersebut menunjukan adanya minat dan 
motivasi antusiasme siswa dalam mengikuti proses pembelajaran pada materi Lingkungan Hidup dan Pembangunan Berkelanjutan dengan menggunakan model Pembelajaran Kooperatif Tipe Snowball Throwing.

Pada siklus I berdasarkan hasil yang diperoleh dari analisis deskriptif terhadap aktivitas belajar siswa menunjukan skor rata-rata aktivitas belajar siswa pada siklus I sebesar 2,6 yang berkategori Cukup. Berdasarkan refleksi pada siklus I, ada beberapa aktivitas belajar siswa yang masih tergolong kurang dimana siswa belum terbiasa dengan Model Pembelajaran Kooperatif Tipe Snowball Trowing yang diambil diantaranya : 1) Dalam proses pembelajaran siswa kurang mendengarkan/memperhatikan penjelasan mengenai materi pelajran yang di sampaikan oleh guru; 2) Siswa kurang aktif dalam proses pembelajaran sehingga siswa kurang menjawab pertanyaan yang diberikan oleh guru dengan benar; 3) Siswa kurang aktif dan kurang kompak untuk berdiskusi dengan kelompoknya dalam memecahkan masalah; 4) Siswa dalam proses pembelajaran Masing-masing kelompok kurang aktif dalam menyimak menanggapi mempresentasikan hasil diskusi di depan kelas. Berdasarkan hal ini siswa tidak menyimak penguatan dan koreksi dari guru tentang hasil diskusi kelompok. Dan berdasarkan refleksi yang terdapat pada aktivitas guru sendiri pada siklus 1 , terdapat beberapa kekurangan yang dialami oleh guru dalam proses pembelajran, beberapa keurangan tersebut ialah : 1) Guru kurang dalam membuka pelajaran dan memeriksa kesiapan siswa tentang materi yang akan di pelajari dan guru kurang memberikan motivasi kepada siswa agar proses pembelajaran berhasil; 2) Guru dalam mengevaluasi dan merefleksi kurang menyimpulkan terhadap hasil diskusi tentang proses mengajar; 3) guru tidak memberikan penghargaan kepada siswa tiap dari akhir diskusi.

Pada siklus I ditemukan ada beberapa aktivitas siswa yang masih belum terlaksana dengan baik.Oleh karena demikian dilakukan perbaikan pada siklus II selanjutnya.

Pada siklus II dari hasil analisis deskritif yang di lakukan terhadap skor ratarata aktivitas belajar siswa pada siklus menunjukan adanya peningkatan pada hasil belajar dari proses pembelajaran yang signifikan dari aktivitas belajar siswa siklus I. Dimana skor rata-rata aktivitas belajar siswa pada siklus II sebesar 3,6 dengan kategori Baik. Hal ini menunjukan bahwa hasil proses pembelajaran penelitian telah berhasil karena telah memenuhi standar minimal aktivitas siswa yaitu 3,0.

\section{Aktivitas Mengajar Guru}

Berdasarkan permasalahan kedua yaitu mengenai bagaimana gambaran aktivitas mengajar guru dengan setelah menerapkan Model Pembelajaran Kooperatif tipe Snowball Throwing, dijelaskan berdasarkan pada hasil pengamatan aktivitas mengajar guru pada setiap siklus baik itu siklus I maupun dari siklus II yang menunjukan peningkatan dari hasil ke 2 siklus tersebut kearah yang lebih baik.

Berdasarkan analisis deskriptif aktivitas Guru pada siklus I menunjukan dari hasil proses belajar dengan rata-rata aktivitas guru yang sebesar 2,67 yang berkategorikan Cukup dimana aktivitas guru pada siklus I ini masih rendah bila di lihat dari hasil yang seharusnya tercapai, guru masih kurang dalam merefleksi yaitu sebab diantaranya yaitu : 1) Guru kurang dalam membuka pelajaran dan memeriksa kesiapan siswa tentang materi yang akan di pelajari dan guru kurang memberikan motivasi kepada siswa agar proses pembelajaran berhasil; 2) Guru dalam mengevaluasi dan merefleksi kurang menyimpulkan terhadap hasil diskusi tentang proses mengajar; 3) guru tidak memberikan penghargaan kepada siswa tiap dari akhir diskusi.

Berdasarkan hasil refleksi terhadap aktivitas guru, dengan mengetahui kekurangan-kekurangan pada siklus I, guru memperbaiki cara mengajarkan materi pembelajaran yang sesuai dengan Model 
Pembelajaran tipe Snowball Throwing sehingga diharapkan pada pertemuan selanjutnya diperoleh peningkatan aktivitas guru pada siklus selanjutnya.

Pada siklus II aktivitas mengajar guru menunjukan peningkatan yang signifikan, dimana pada siklus II skor rata-rata aktivitas guru memperoleh nilai sebesar 3,67 yang berkategorikan Baik. Hasil analisis dan pengamatan pada siklus II ini menunujukan adanya peningkatan aktivitas guru dengan menerapkan Model Pembelajaran Kooperatif tipe Snowball Throwing. Hal ini menunjukan bahwa penelitian telah berhasil karena telah memenuhi standar minimal aktivitas guru yaitu 3,0 .

\section{Hasil Belajar Siswa}

Berdasarkan permasalahan ketiga, yaitu apakah melalui penerapan Model Pembelajaran Kooperatif tipe Snowball Throwing dapat meningkatkan hasil belajar Geografi siswa kelas XI SMA Negeri 1 Lasalimu Selatan pada materi pokok pembelajaran Lingkungan Hidup dan Pembangunan Berkelanjutan dapat dijelaskan bahwa berdasarkan hasil analisis deskriptif kuantitatif yang dilakukan terhadap hasil belajar siswa pada setiap siklus cenderung mengalami peningkatan kearah yang lebih baik.

Pada siklus I berdasarkan hasil tes hasil belajar siswa pada siklus I diperoleh nilai peresentase ketuntasan hasil belajar yaitu 65,5\% sesuai dengan KKM Geografi dan yang belum tuntas dengan presentase sebesar $43,5 \%$ siswa yang nilainya belum mencapai KKM yang di tentukan oleh sekolah yaitu 70. Presentase ketuntasan pada siklus I ini belum mencapai target peneliti yaitu mencapai ketuntasan belajar secara klasikal minimal $80 \%$.

Berdasarkan refleksi pada siklus I yang telah di lalui dengan melihat aktivitas siswa dan hasil belajar, maka dapat mengambil kesimpulan bahwa dalam proses pembelajaran tampak bahwa siswa kurang antusias atau pun kurangnya semangat sehigga pada siklus I ini belum bisa tercapai, hal ini dapat di tunjukan dalam kegiatan belajar mengajar yaitu : 1) Dalam proses pembelajaran siswa kurang mendengarkan/memperhatikan penjelasan mengenai materi pelajaran yang di sampaikan oleh guru; 2) Siswa kurang aktif dalam proses pembelajaran sehingga siswa kurang menjawab pertanyaan yang diberikan oleh guru dengan benar; 3) Siswa kurang aktif dan kurang kompak untuk berdiskusi dengan kelompoknya dalam memecahkan masalah; 4) Siswa dalam proses pembelajaran Masing-masing kelompok kurang aktif dalam menyimak menanggapi mempresentasikan hasil diskusi di depan kelas.

Setelah melakukan analisis dan refleksi hasil belajar siswa pada siklus I. guru mata pelajaran dan peneliti mencoba melakukan perbaikan dalam proses belajar mengajar agar pada siklus selanjutnya siswa yang memenuhi ketuntasan belajar dapat meningkat seperti yang diharapkan.

Selanjutnya pada siklus II sesuai dengan hasil yang telah diperoleh pada hasil tes belajar siswa pada siklus akhir, terlihat bahwa hasil belajar siswa memperoleh nilai minimum 60 nilai maksimun 100 rata-rata hasil belajar siswa 76,6 secara klasikal ketuntasan hasil belajar yang di peroleh sebesar $89,7 \%$ dan nilai yang di tentukan untuk memperoleh sesuai hasil belajar di bawah KKM ialah 70 pada siklus II ini terdapat 3 orang siswa yang belum tuntas dengan presentase sebesar $10,3 \%$ dan sisanya terdapat 26 orang siswa yang memenuhi kriteria kentuntasan dari hasil belajar dengan pesentase $8,9 \%$. Dari hasil tersebut menunjukan peningkatan dari siklus I ke siklus II yang secara signifikan, walaupun demikian masih tersisa 3 dari 29 orang siswa yang belum memenuhi dari criteria yang akan di capai oleh semua siswa pada ketuntasan belajar.

Karena indicator keberhasilan dalam penelitian ini telah tercapai dalam hal ini terlihat pada siklus II target kentuntasan hasil belajar telah tuntas dalam hasil belasjar. Hal ini penelitian dianggap telah berhasil mencapai targetnya. Dalam 
penelitian ini keberhasilan siswa dalam tes hasil awal belajar siklus I sampai dengan siklus II dengan siklus II memberikan gambaran bahwa penerapan model pembelajaran Kooperatif tipe Snowball Throwingmampu meningkatkan hasil belajar siswa.

Dengan demikian, jawaban atas permasalahan penelitian telah ditemukan yaitu pembelajaran dengan Model Pembelajaran Kooperatif tipe Snowball Throwing berhasil meningkatkan aktivitas belajar siswa dalam proses pembelajaran serta meningkatkan hasil belajar siswa Geografi siswa kelas XI SMA 1 Negeri Lasalimu Selatan pada materi Lingkungan hidup dan pembangunan berkelanjut.

\section{PENUTUP}

\section{A. Kesimpulan}

Berdasarkan refleksi dan diskusi peneliti dengan observer pada bab sebelumnya, maka peneliti dapat menyimpulkan bahwa model pembelajaran Kooperatif tipe Snowball Throwing dapat meningkatkan hasil belajar siswa SMA Negeri 1 Lasalimu Selatan pada materi Lingkungan hidup dan pembangunan berkelanjutan ditujukan sebagai berikut :

1. Penerapan model pembelajaran Kooperatif tipe Snowball Throwing dalam pembelajaran Geografi dapat meningkatkan aktivitas belajar siswa SMA Negeri 1 Lasalimu Selatan tahun pelajaran 2017/2018. Hal tersebut dapat dilihat hasil pengamatan proses pembelajaran mulai dari siklus I dengan skor rata-rata aktivitas belajar siswa adalah 2,6 termaksud kategori cukup meningkat pada siklus II menjadi yang 3,6 termaksut pada kategori Baik.

2. Aktivitas mengajar guru dengan menerapakan model pembelajaran Kooperatif tipe Snowball Throwing menunjukan adanya peningkatan yang signifikan terhadap hasil belajar pada setiap siklus cenderung meningkat. Hal tersebut dapat dilihat pada skor rata-rata aktivitas guru pada siklus I 2,67 termaksud kategori cukup dan siklus II 3,67, yang berkategori Baik.
3. Hasil belajar Geografi siswa kelas XI SMA Negeri I Lasalimu Selatan dengan menerapkan model pembelajaran Kooperatif tipe Snowball Throwing pada materi Lingkungan hidup dan pembangunan berkelanjutan. Dimana pada siklus I presentase ketuntasan sebesar 65,5\% ,yang mencapai KKM.Pada siklus II yaitu dengan nilai rata-rata76,6 dengan presentase ketuntasan sebesar $89,7 \%$ yang mencapai KKMsiklus II mengalami peningkatan terhadap hasil belajar siswa.

\section{B. Saran}

Mengingat rendahnya hasil belajar siswa pada materi pelajaran Geografi, maka untuk mengatasi hal tersebut model pembelajaran Kooperatif tipe Snowball Throwing sangat efektif untuk meningkatkan hasil belajar siswa.

1. Dalam penelitian ini materi yang menjadi pokok bahasan adalah lingkungan hidup dan pembangunan berkelanjutan maka di harapkan untuk peneliti selanjutanya dapat digunakan untuk menerapkan model pembelajaran Kooperatif tipe Snowball Throwing untuk materi-materi lain.

2. Dapat menjadi bahan masukan bagi pengajar tentang medel pembelajaran yang inovatif dan efektif, sehingga dalam proses belajar mengajar tidak terpaku pada satu model pembelajaran saja.

\section{DAFTAR PUSTAKA}

Departemen Pendidikan Nasional (2008) Kamus Besar Bahasa Indonesia Pusat Bahasa. Jakarta: PT Gramedia Pustaka Utama.

Isjoni, 2011 Pembelajaran Kooperatif, Yogyakarta: Pustaka Pelajar.

Ismail, 2003.Media Pembelajaran ( ModelModel Pembelajaran), Jakarta Proyek Peningkatan Mutu SLTP.

Kokom Komalasari, 2010. Pembelajaran Kontekstual : Konsep dan Aplikasi, Bandung: PT Refika Aditama. 
Nana Sudjana. 2002. Penilaian Hasil Proses Belajar Mengajar, Bandung: Remaja Rosdakarya.

Susetyo, Budi. 2010. Statistika Untuk Analisi Data Penelitian. Penerbit Refika Aditama.

Rusman, 2011 Model-model Pembelajaran: Mengembangkan Profesionalisme Guru, Jakarta: PT Raja Grafindo Persada.

Sagala, 2009:12 Pengertian belajar dalam peningkatan aktivitas dan hasil belajar ips melalui model pembelajran kooperatif tipe snowball throwing pada siswa kelas IV SDN 2 suka bumi kecamatan suka bumi kota Bandar lampung tahun pelajaran 2014/2015.Fakultas keguruan dan ilmu pendidikan, Universitas Lampung.

Sanjaya Wina, 2009. Strategi pembelajaran Berorientasi Standar Proses Pendidikan, Jakarta: Prenada Media Group.

Suprijono, Agus (2011) Cooperative Learning Teori dan Aplikasih Painkem Yogyakarta Pustaka Pelajar.

Usman, M.U dan Setiawati, L 2011. Upaya Optimalisai Kegiatan Belajar Mengajar. Bandung: PT, Remaja Rosdakarya. 